\title{
$\left[\begin{array}{ll}135 & ]\end{array}\right.$
}

\section{VIII.-Remarks on some Fossil and Recent Shells, collected by Captain Bay- field, R.N., in Canada.}

\author{
By CHARLES LYELL, EsQ., V.P.G.S., F.R.S.
}

[Read April 24, 1839.]

\section{Plate XVI.}

SEvERAL eminent conchologists have observed, that in some strata of the English crag there are certain species and genera of shells which seem to indicate a somewhat colder climate than that which now prevails in our latitudes; and it has been supposed that a similar inference may be deduced with still greater certainty from the abundant occurrence of many arctic species in the most modern of the marine Newer Pliocene strata of Scotland and Ireland. These opinions induce me to offer some remarks on a collection of fossil and recent shells which have lately been sent to me from Canada by Captain Bayfield, who procured the fossils from the newest tertiary deposits bordering the Gulf of St. Lawrence, and the recent Testacea from the Gulf itself.

The shells were found principally at Beauport, on the east bank of a river of that name, which enters the St. Lawrence on its northern side about two miles below Quebec, in lat. $47^{\circ}$; but the same formation is traced in the valley of the St. Charles and many other places, at heights varying from 30 to 300 feet above the Gulf.

"The strata," says Captain Bayfield, "are of sand, gravel, and stiff blue clay, similar to deposits at present forming lower down, as well as higher up, the St. Lawrence. They fill a valley previously formed in an ancient horizontal limestone, containing Trilobites, Orthocerata, \&c. Angular fragments of this limestone, and a Trilobite washed out of its matrix, were found amongst the modern shells. The upper stratum of sand is nearly 100 feet above the St. Lawrence, and is almost exclusively composed of bivalves. The strata have been traced a mile up the valley on the east bank of the Beauport river, the ancient limestone forming the west bank. Similar shells were also met with, at a still higher elevation, on the north side of the valley of the St. Charles, about three miles from Beauport. In these and all other localities of the same formation, the lowest strata usually consist of clay, and the uppermost of sand and clay mixed. It is in these last that the shells are abundant, being rare in the stiff blue clay. 
"The tertiary strata," says Captain Bayfield, "contain numerous boulders of primary rocks, which occur at different levels, not resting upon each other, but as if they had been dropped there at widely different times during a long period in which a quiet deposition of clay, sand and gravel had been going on, and in which the various genera of Testacea had lived and died. Of course some of the shells are broken, and some of the valves separate, as is found in the bottom of the present sea; but many have both valves together as they lived, although they separate when taken up, because the ligament no longer exists. But all idea of these shells, together with the clay, sand, gravel and boulders having been drifted together into their present position by a violent current or rush of water, must be given up at once when I state the fact, that the Terebratula psittacea, which you know are so fragile that the smallest stones would be sufficient to destroy them if carried along even with a moderate degree of violence by moving water, are found with their valves together, and their long and brittle teeth entire as when they were living. The whole of the facts lead me to infer, that these numerous erratic blocks have been carried by ice, and dropped from time to time on the bed of the tertiary sea."-(Extract from letter, dated 11th November, 1835.)

Deposits containing the same fossil shells were also found at Port Neuf, forty miles above Quebec, in terraces of clay and sand, which rise to different levels above the St. Lawrence, and parallel to its course. They occur at heights varying from 50 to 200 feet above the river.

When I first.received these fossil shells from Captain Bayfield, I was struck with their great resemblance to those which I had collected at Uddevalla, in Sweden; and this similarity was confirmed by Dr. Beck, after a minute examination. The Saxicava rugosa, so predominant at Uddevalla, is particularly mentioned by Captain Bayfield as the most numerous shell in all the deposits, and the Natica clausa and Pecten islandicus are very common, as at Uddevalla. On the other hand, the fossils at Beauport, considered as a whole, by no means agreed with the marine shells now inhabiting the Gulf of St. Lawrence. For the names of most of the Beauport shells in the following list, I am indebted to Dr. Beck, who determined, in 1836 , all that $I$ had then received.

\section{List of Fossil Shells from Beauport, near Quebec.}

1. Tritonium Anglicanum, a Newfoundland and Greenland species, or variety, according to some authors, of Buccinum undatum. See Pl. XVI. figs. 1, 2. No. 2 has the ridges less prominent.

2. T. fornicatum, Fabric. Fauna Gröenlandica, 399. It is the Fusus carinatus, Lamk. (See Pl. XVI. fig. 3.) Recent from Bic, Canada. Dr. Lovén has it recent from Finmark. T. fornicatum is considered by most authors as a variety of Fusus despectus, a Greenland species or variety, but which seems also undistinguishable from one now recent at Cork, in Ireland, and which is also found fossil at Dalmuir, in the Firth of Clyde.

3. Natica clausa (N. septentrionalis, Beck), Brod. and Sow., Zoological Journal, vol. iv. p. 372. Beechey's Appendix, Pl. XXXIV. fig. 3, and Pl. XXXVII. fig. 6, a species still living in Greenland, the North Sea, and North America. Very common at Uddevalla.

4. Scalaria borealis, Philosophical Transactions, 1835, Pl. II. figs. 11, 12. Living in Greenland seas, according to Beck.

5. S. Gröenlandica, var.? (Pl. XVI. fig. 4.) Dr. Beck was of opinion that this might be the same as 
the recent shells figured by Chemnitz, and now living in the Greenland seas, but if so the fossil species constitute a marked variety, the varices being more slender and more lamellar at their posterior ends.

6. Mya truncata (Pl. XVII. fig. 5, 6.). Shell shorter than the common form, and the posterior truncation oblique, and inclined to the basal margin, and with a smaller sinus in the muscular impression. This variety is identical with one found fossil by Mr. Smith in Bute, and considered as an extinct species, but I have the same recent from the St. Lawrence, and intermediate varieties between it and the normal form of M. truncata.

7. Mya arenaria. One valve; the same is also recent in the Gulf of St. Lawrence. I have not seen this shell, but it was identified by Captain Bayfield, who sent me recent shells from the same.

8. Saxicava rugosa. Port Neuf. The two varieties of this species which prevail at Uddevalla are also common at Beauport. One of these I have figured in the Phil. Trans. 1835; Pl. II., the other with the umbones more central is figured in the annexed Plate XVII., fig. 7. There are intermediate ones between these two.

9. Tellina gröenlandica, Beck. (PI. XVII., fig. 8 a., 8 b.). Also living in the Gulf of St. Lawrence; and at the Icy Cape, according to Mr. G. Sowerby.

10. Tellina calcarea, var.? Wahlenberg, p. 36. (T.proxima, Brown, T.triangularis, Phil. Trans. 1835 ; Pl. XVII., fig. 9, 10, 11.). The fossil from Canada differs slightly from that which is so com. mon at Uddevalla, and from the same which occurs fossil at Bute, both in its larger size and in the form of the palleal impression, which does not extend so far forward. See Pl. XVII figs. 9,10 . I have a recent one from the Norway seas identical with the Uddevalla variety.

11. Nucula. One broken valve which I have not seen.

12. Mytilus edulis.

13. Pecten islandicus. Living in the North Sea; not known as British, but occurring in the newer Pliocene beds in Scotland.

14. Terebratula psittacea, var. Scarcely showing any of those traces of longitudinal striæ which are common in the living species from Labrador, but considered by Dr. Beck and Mr. Sowerby to be the same as the recent species, which has a wide geographical range, occurring in Greenland and the Feroe Islands, and half-way between these islands and Denmark.

15. Balanus Uddevallensis, Lin. (B. scoticus). Same as the large Balanus found fossil at Uddevalla, and not distinguishable from $B$. scoticus (genus Chirona of Gray), a British species found in the German Ocean off Scarborough. The Uddevalla and Beauport specimens are similarly striated externally. (See Phil. Trans. 1835 ; p. 37.)

16. Balanus miser, Gould, (Pl. XVII., fig. 12 a.,) f. 12 b. is a single valve of an elongated variety.

17. Echinus. Fragments apparently identical with a living species found in the Gulf of St. Lawrence.

Although the fossil species amount to no more than sixteen, the number of individuals examined was very great, affording in this respect a striking analogy to the deposits near Uddevalla in Sweden. This limited variety of species, so different from that observed in the present fauna of the neighbouring gulf, seems to favour the hypothesis that the climate was formerly much colder.

For the sake of comparison I subjoin a list of the recent marine shells of the Gulf of St. Lawrence, forwarded to me by Capt. Bayfield, in the naming of which I have been assisted by Dr. Beck and Mr. George Sowerby. 


\section{2.' List of Recent Marine Shells collected in the Gulf of St. Lawrence.}

1. Pholas crispata.

2. Glycimeris siliqua.

3. Solen Americanus.

4. Solenocurtus nitidus, Say.

5. - costatus, Say.

6. Mya truncata.

7. arenaria.

8. Pandora trilineata, Say.

9. Anatina Leana, Conrad. (Cochlodesma Leana, Couthouy, Boston Journ.) Rare in Gulf of St. Lawrence.

10. Mactra ovalis, Gould. (M. similis, Gray, MS. in Brit. Mus., Beechey Zool. T. xliv., f. 8.)

11. Mactra solidissima, Say. (M. giganteum, Chemnitz.)

12. Mesodesma Jauresii. (Joannis in Mag. de Zool. t. liv. 1834.)

13. Saxicava rugosa, both the varieties mentioned in the preceding list of fossil shells.

14. Petricola pholadiformis.

15. Tellina gröenlandica, Beck. (Sanguinolaria fusca of American authors.)

16. Venus mercenaria.

17. Astarte borealis, var.

18. - sulcata.

19. —_, probably N.S.

20. ——, allied to compressa, perhaps identical.

21. Cardium gröenlandicum, Lamk. (Aphrodite columba, Lea; Amer. Phil. Trans.)

22. Cardium islandicum.

23. Nucula myalis, Couthouy.

24. — concentrica, Say.
25. Mytilus edulis.

26. Modiola glandula, Gould. Rare in the St. Lawrence.

27. - plicatula?

28. —_ papuana.

29. Pecten islandicus.

30. — magellanicus, Lamk.

31. Ostrea Americana.

32. Balanus costatus.

33. - miser.

34. Buccinum undatum.

35. - cyaneum, Brug. (Tritonium cyaneum, Beck.) Query var. of B. undatum.

36. ——, N.S., allied to B. undatum.

37. obsoletum. (Nassa obsoleta, Say.)

38. Nassa trivittata, Say.

39. Purpura lapillus, viar.

40. Rostellaria occidentalis. (Aporrhais occidentalis.)

41. Fusus carinatus, Lamk.

42. - , allied to or identical with recent species from Icy Cape.

43. - $\longrightarrow$ N.S., allied to F. turricula.

44. - N.S., also allied to F. turricula. (Murex turricula, Mont.)

45. Natica ampullaria, Lamk. (N. heros, Say.)

46. Turritella erosa, Couthouy.

47. Littorina vestita. (Turbo vestitus, Say.)

48. - palliata. (Turbo palliatus, Say.)

49. Lacuna vincta, Turton.

50. Margarita striata.

51. Crepidula fornicata.

52. Patella testudinalis. (Lottia, Gray.)

The torrents and rivers, says Capt. Bayfield, which flow into the St. Lawrence sweep down annually into that estuary great numbers of fossil shells from the modern tertiary deposits, so that they are mingled with living shells, and thus the productions of two periods are confounded together. Of this intermixture there appear abundant examples in a collection of shells dredged up by Capt. Bayfield from the mud at the bottom of the Gulf of St. Lawrence, near the island of Bic, where the water was between fifteen and sixteen fathoms deep. Among these the recent shells may generally be distinguished by retaining their colour, animal matter, or ligaments. It is more difficult to feel sure respecting those which have been exclusively derived from the tertiary deposits, but $I$ have little doubt that to this number belong several specimens of the Balanus Uddevallensis, (fifteen of list No. 1.) and a Fusus, nearly allied to F. lamellosus, Lam., a species now living at Icy Cape, N. lat. $70^{\circ}$, and common at Uddevalla*. Both of these shells have been

* Phil. Trans., 1835, p. 37, where it is called Rumphius, misprint for F. Bamfius. 
dredged up at Bic, in the same state as the Beauport fossils, but none of those sent to me were in the state of recent shells.

The newer Pliocene fossils therefore of Canada, so far as they have been hitherto examined, belong to species which either range in a living state from the Gulf of St. Lawrence to the borders of the north polar circle, or are now only known in high northern latitudes, as in the seas of Greenland, Iceland, and Norway, or agree with varieties or species found in the newer Pliocene deposits of Scotland and Sweden. On the other hand, many of the living species of shells now most conspicuous from their size or abundance in the Gulf of St. Lawrence are wanting in the collection of fossils hitherto obtained, as for example, Mactra solidissima, Mesodesma Jauresii, Purpura Lapillus, var., Natica Heros, Rostellaria occidentalis, and several others.

It would doubtless be rash to insist positively on any general conclusions which we may be tempted to draw from so small a number of fossil shells as those hitherto procured in Canada, but judging from them alone, they approach more nearly to the fossils of the most modern deposits of northern Europe than do the actual faunas of Europe and America in corresponding latitudes. The number of testacea indeed hitherto regarded as common to the opposite sides of the Atlantic is very small. Eleven only were known to Dr. Beck in 1836, and Mr. George Sowerby was able to add no more than four or five after a recent comparison of a large collection of shells of North America with those of Europe ; and the fifty-two recent shells obtained by Capt. Bayfield from the St. Lawrence have only contributed one more to the number, namely, Cardium islandicum, which inhabits the northern parts of the German Ocean. Capt. Bayfield informs me that he also discovered the Cardium islandicum fossil at Port Neuf, although in too disintegrated a state to be preserved.

As the climate of Canada is now excessive, it is natural that we should find in the Gulf of St. Lawrence many northern and arctic species, and no mixture of tropical forms, for these last cannot resist severe cold, although we know from the analogy of the southern hemisphere that they can extend far toward polar latitudes, dispensing with a high temperature in summer provided the winters be mild.

It is very probable, therefore, that in the period immediately antecedent to the present the climate of Canada was even more excessive than it is now, and that the shells resembled still more closely that small assemblage now found in high northern latitudes. This extreme cold may have coincided with the era of the principal transportation of erratic blocks, which have reached the $36^{\circ} 30^{\prime}$ degree of latitude in North America*.

* Darwin, Journal of Travels in South America, in Voyage of H. M. S. Beagle, Appendix, p. 614, who cites Rogers. 
It is evident from the manner in which large fragments of rock are irregularly interspersed among the shelly strata near Quebec, as described by Capt. Bayfield, that when these deposits were taking place the transportation of blocks by ice was going on continually, as at the present moment, in the St. Lawrence.

I have mentioned that many of the testacea which now inhabit the Gulf of St. Lawrence, lat. $48^{\circ} \mathrm{N}$., and some others which are found fossil in the Beauport beds, are of the same species which now live in the Northern Ocean between the latitudes $60^{\circ}$ and $75^{\circ} \mathrm{N}$. Perhaps the constant melting of ice in the Gulf may have some influence in promoting the range of northern species by cooling the waters to a temperature below that of the air in summer. This effect may be produced not only by the great quantity of ice which is drifted in the spring from Baffin's Bay along the coast of Labrador and then through the Straits of Belle Isle into the Gulf of St. Lawrence, but also by the ice which descends the St. Lawrence itself. This cause may help to assimilate the temperature of the sea in Canada at a certain depth to that which belongs to it nearer the surface much farther north. The wide distribution of species alluded to may be favoured, not only by the direction of the great current which runs from Baffin's Bay southward, and which may drift along the eggs of mollusca, or their young, but also by the ice islands themselves, which are continually stranding on all parts of the coasts and again leaving the same, so that they may carry away with them not only mud, sand and blocks of granite, but also many entire and living shells.

In a letter, dated Nov. 1837, Capt. Bayfield says, " Last spring I watched the ice of Lake St. Peter, which takes two or three days to pass Quebec every spring, and had the pleasure to observe several boulders of considerable size, and many small stones, sand, earth, reeds, and plants on their way down the river, drifting along at a rate measured by the excess of every ebb tide over the preceding flood. The latter flows $4 \frac{3}{4}$ hours at the rate of three knots, the former about $7 \frac{1}{2}$ hours at four knots. Any boulders and other matters which are thus transported are liable to be dropped, at various points along the bed of the river, as the ice gives way to the increasing temperature of the air and water in the spring of the year. The freshwater shells, which are often found washed up on the beaches, are doubtless carried low down the estuary in this way, being frozen into the mass of ice which forms on the shoals where they abound."

I have spoken of the deposit at Beauport and other places as belonging to the most modern tertiary or newer Pliocene period, and the only doubt which can be entertained as to its age is, whether it ought rather to be referred to the post-tertiary era, or to that in which all the shells are identical with species now existing. As the number hitherto obtained amounts to no more than sixteen, it would be premature to offer a positive opinion on this subject. Some conchologists would 
probably incline to believe, that two shells of the above list which I have figured, Scalaria gröenlandica and Tellina calcarea, ought to be regarded as new and distinct species. In every case it seems clear that when the Beauport fossils were deposited the testaceous fauna approached more nearly to that now established in the arctic regions, than to that which characterizes at present the Gulf of St. Lawrence; and the small number of species, amid so great a profusion of individuals, affords, as before hinted, a strong argument in favour of the greater severity of the climate at an epoch immediately antecedent to the present. Nor should we be surprised at discovering that there have been oscillations of climate in times which are, comparatively speaking, of recent date, when we see proofs of considerable geographical changes within the same epoch, namely, those which in Canada have converted sea into land, and raised the shelly strata above described to the height of 300 feet.

I think it probable that this extreme climate prevailed at once in the north of Europe and in Canada at the time when the shelly strata of Scandinavia and the basin of the St. Lawrence were simultaneously accumulated, and that there was then a more close resemblance between the shells living in these latitudes, on either side of the Atlantic, than we find at the present epoch.

\section{Description of Plate XVII.}

Fig. 1, 2. Tritonium anglicanum. (Buccinum undatum ?) Fig. 2 has the ridges less prominent.

Fig. 3. T. fornicatum, Fab. (Fusus carinatus, Lamk.)

Fig. 4. Scalaria Gröenlandica, var.?

Fig. 5, 6. Mya truncata.

Fig. 7. Saxicava rugosa, variety having the umbones more central.

Fig. 8. Tellina Gröenlandica, Beck. Fig. 8. a. shows the outer, and 8. b. the inner side.

Fig. 9, 10, 1]. Tellina calcarea, var.? Wahlenberg. (T. proxima, Brown, T. triangularis, Phil. Trans. 1835, p. 36.)

Fig. 12. Balanus miser, Gould. 12 a. shows the ordinary form; 12. b. represents a single valve of an elongated variety.

The above eight species found fossil at Beauport, Canada. 


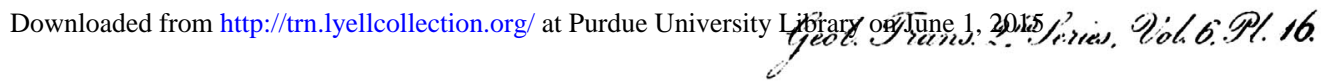
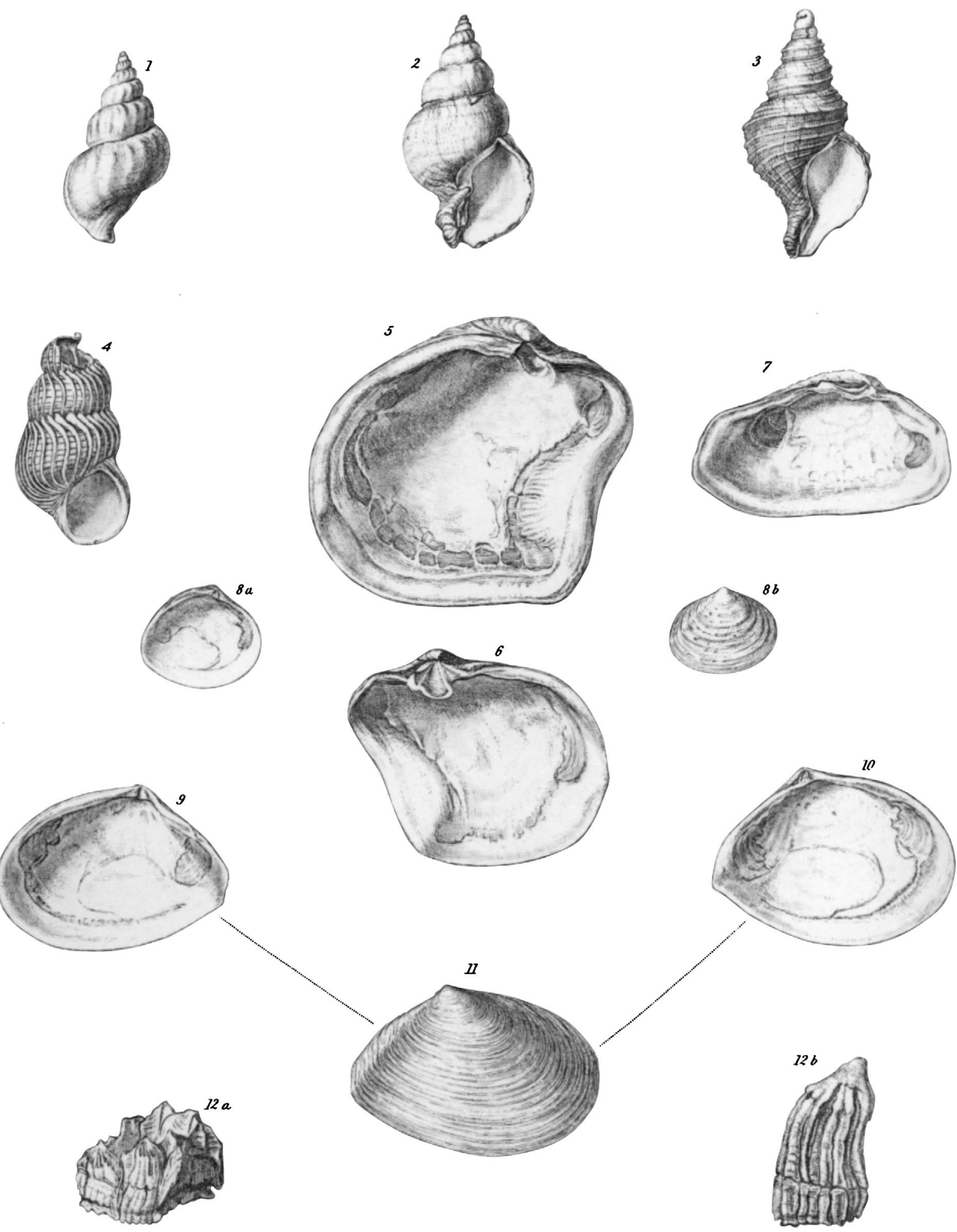

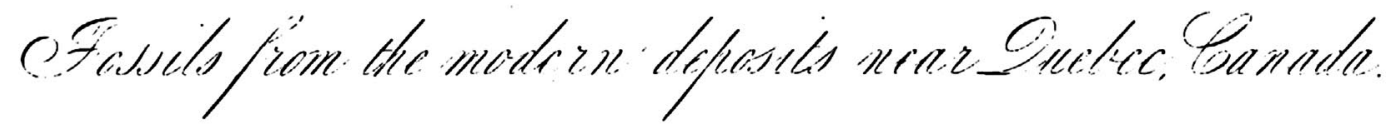

